\title{
Effect of cassava chips on quality of silage from fresh forage sorghum plus Cavalcade forage legume hay mixtures
}

\author{
SURADEJ PHOLSEN ${ }^{1}$, CHUTCHAWAL YOOTTASANONG $^{1}$ AND DAVID E.B. HIGGS ${ }^{2}$ \\ ${ }^{1}$ Department of Animal Science, Faculty of Agriculture, Khon Kaen University, Khon Kaen, Thailand. www.kku.ac.th \\ ${ }^{2}$ School of Life Sciences, University of Hertfordshire, Hatfield, Hertfordshire, UK. www.herts.ac.uk
}

Keywords: DMD, CP, sorghum silage, grass-legume silage, Centrosema pascuorum, silage additives.

\begin{abstract}
Two experiments investigated the effects on silage quality of adding cassava chips at a range of levels to a sorghum forage plus Cavalcade legume hay mixture at ensiling at the Experimental Farm, Khon Kaen University, Thailand. Cavalcade hay was $15 \%$ of chopped sorghum fresh weight and cassava chips were added at $0,5,10$ and $15 \%$ of chopped sorghum fresh weight. The first experiment utilized sorghum and Cavalcade main crops and the second used the ratoon crop of sorghum and $2^{\text {nd }}$ cut of Cavalcade. Dry matter percentage of ensiled mixtures and silages increased $(\mathrm{P}<0.05)$ with an increase in cassava chip levels in both experiments, but $\mathrm{CP}$ and NDF concentrations decreased $(\mathrm{P}<0.05)$. Dry matter degradability increased $(\mathrm{P}<0.05)$ with an increase in cassava chip levels up to $10 \%$ in both main and ratoon $/ 2^{\text {nd }}$ cut silages. Digestible energy and metabolizable energy of both silages increased significantly with an increase in cassava chip levels up to $10 \%$ for main crop and $15 \%$ for ratoon $/ 2^{\text {nd }}$ cut crops. While addition of cassava chips improved digestibility and energy content of silage, it lowered CP concentration. Use of fresh Cavalcade instead of hay should increase the CP levels and should be investigated along with animal feeding studies to test acceptance and animal performance.
\end{abstract}

\section{Resumen}

En el campo experimental de la Universidad Khon Kaen, Tailandia, se realizaron sendos experimentos para evaluar el efecto de la adición de trozos (chips) de yuca (Manihot esculenta) en la calidad del ensilaje de una mezcla de sorgo forrajero con heno de la leguminosa forrajera Centrosema pascuorum cv. Cavalcade, este último en una proporción de $15 \%$ del peso verde del sorgo en la mezcla. Los chips se agregaron en proporciones de 0, 5, 10 y $15 \%$ del peso fresco del sorgo picado. En un primer ensayo se utilizaron sorgo y cv. Cavalcade de la primera cosecha (material de plantas previamente no cortadas) y en el segundo, material proveniente de plantas rebrotadas después de un primer corte. El porcentaje de materia seca (MS) de las mezclas tanto al momento de ensilar como del ensilaje ya listo para consumo, aumentó $(\mathrm{P}<0.05)$ en la medida que en ambos ensayos los niveles de chips de yuca en la mezcla aumentaron. No obstante, los porcentajes de proteína cruda $(\mathrm{PC})$ y fibra detergente neutra disminuyeron $(\mathrm{P}<0.05)$. La degradabilidad de la MS aumentó $(\mathrm{P}<0.05)$ con el incremento del nivel de chips (hasta el nivel 10\%) en ambos experimentos. Las energías digestible y metabolizable de ambos ensilajes aumentaron $(\mathrm{P}<0.05)$ con el incremento del nivel de chips hasta el nivel $10 \%$ en el primer ensayo y $15 \%$ en el segundo. Mientras que la adición de chips de yuca mejoró la digestibilidad y el contenido de energía del ensilaje, redujo la concentración de PC. Se sugiere estudiar si el uso de material fresco de la leguminosa en lugar de heno incrementa las concentraciones de PC en el ensilaje. Además se sugiere conducir estudios con animales para evaluar la aceptabilidad de los ensilajes y su efecto sobre la producción animal.

Correspondence: S. Pholsen, Department of Animal Science, Faculty of Agriculture, Khon Kaen University, Khon Kaen 40002, Thailand.

Email: $\underline{\text { surpho@kku.ac.th }}$ 


\section{Introduction}

Sorghum cultivation for use as livestock feed in Thailand began in 1962. Sorghum cultivars were compared from 1962 to 1966 to select for grain yield and quality (Senanarong 1977). Subsequent research concentrated on forage sorghum (Suchato et al. 1991; Phaikaew et al. 1992; Pothisoong et al. 2005). A comparison of dry matter (DM) yields of 10 sorghum varieties for forage showed that cultivar IS 23585 was the most suitable for use in Northeast Thailand, producing high DM yield and good nutritive value in both main and ratoon crops (Pholsen et al. 1998, 2001; Pholsen and Higgs 2005).

Water soluble carbohydrates (WSC) in ensiled crops are a source of energy for bacteria to produce lactic acid and lower $\mathrm{pH}$ to $<4.2$ for good silage quality (McDonald et al. 1991; Miron et al. 2007). High sucrose content (measured as brix value, one kind of WSC) in forage sorghums results in good silage quality (Phaikaew et al. 2003; Pholsen and Sornsungnoen 2004). Although excellent silages can be made from forage sorghums, crude protein $(\mathrm{CP})$ concentrations decrease with increase in stage of maturity (Black et al. 1980; Pholsen and Higgs 2005). This drop in CP can be counteracted by including a forage legume at ensiling, e.g. sugarcane tops plus leucaena (Leucaena leucocephala) leaves (Sangchote et al. 1992) or pangola grass (Digitaria eriantha) plus Thapra stylo (Stylosanthes guianensis CIAT 184) (Khuamangkorn et al. 2006). Higher WSC in the forage legume Cavalcade centro (Centrosema pascuorum cv. Cavalcade) than Thapra stylo resulted in a lowered silage $\mathrm{pH}$ (Namsele et al. 2007).

The quality, both DM and CP, of low-DM (highmoisture) grass silage can be improved with the addition of legume hay (Church and Pond 1988; Wilkinson 1990). Adding $8 \%$ ground Cavalcade hay plus 5\% cassava chips to Napier grass (Pennisetum purpureum) significantly increased DM content, but decreased CP concentration and lowered $\mathrm{pH}$ of silages to $<4.27$ (Pongpeajan et al. 2008). Khota et al. (2009) reported that adding Cavalcade hay at up to $20 \%$ to forage sorghum cultivar IS 23585 at ensiling significantly increased DM, CP and dry matter degradability (DMD) of the silages and all Cavalcade levels produced good silage quality with $\mathrm{pH}$ ranging from 3.38 to 3.70 and $\mathrm{NH}_{3}-\mathrm{N}$ from 1.29 to $1.71 \%$ of total $\mathrm{N}$. They suggested that Cavalcade hay levels from 10 to $20 \%$ of sorghum fresh weight could be the optimum levels to add to forage sorghum with DM contents ranging from 26.6 to $33.9 \%, \mathrm{CP} 8.80$ to $10.65 \%$ and DMD from 58.9 to $59.1 \%$, respectively.

Cassava chips (Manihot esculenta) could be a useful additive to sorghum plus Cavalcade forage for making silage because it is high in energy, has high digestibility and is abundant in Thailand, where it can be produced easily by farmers, although it is low in nitrogen (Chanjula et al. 2003; WTSR 2010). Pongpeajan et al. (2008) found that adding cassava chips at 5\% to Napier grass plus Cavalcade forage resulted in good quality silage, but lowered $\mathrm{CP}$ concentration.

There are, however, no reports of addition of cassava chips to forage sorghum and Cavalcade hay mixtures for silage making. Addition of cassava chips to these materials should result in good silage quality with high digestibility.

This laboratory experiment was designed as a preliminary study to examine the effects of addition of cassava chips to mixtures of forage sorghum and Cavalcade hay on quality, chemical composition, DMD, gross energy (GE), digestible energy (DE) and metabolizable energy (ME) of silages made from both main and ratoon crops.

\section{Materials and Methods}

\section{Sowing ensiled crops}

The sorghum and Cavalcade centro crops for these experiments were grown at the Experimental Farm, Faculty of Agriculture, Khon Kaen University, Khon Kaen, Northeast Thailand from May to November 2008 on Korat Soil Series (Oxic Paleustults). The mean values for soil $\mathrm{pH}$, soil organic matter, $\mathrm{N}, \mathrm{P}$ (Bray II method) and $\mathrm{K}$ were $5.62,1.15 \%, 0.04 \%, 21.8 \mathrm{ppm}$ and $44.3 \mathrm{ppm}$, respectively. An area of $400 \mathrm{~m}^{2}$ was used to grow Cavalcade centro and a similar area alongside the Cavalcade plot for sorghum (Sorghum bicolor).

The plots were plowed twice and harrowed once. Before the second plowing, the soil on the sorghum plot was basal dressed with fermented cattle manure at 40 $\mathrm{t} / \mathrm{ha}$, dolomite $\left[\mathrm{CaMg}\left(\mathrm{CO}_{3}\right)_{2}\right]$ at $3,125 \mathrm{~kg} / \mathrm{ha}$ and $57.5 \mathrm{~kg}$ P/ha. NPK fertilizer (15:15:5) at $312.5 \mathrm{~kg} / \mathrm{ha}$ was applied on the Cavalcade centro plot before harrowing.

Cavalcade seed was sown on 6 June 2008, and sorghum on 11 June at seeding rates of $25 \mathrm{~kg} / \mathrm{ha}$. Sowing was by hand into furrows $5 \mathrm{~cm}$ deep and $50 \mathrm{~cm}$ apart, and seed was covered with soil. Weeds on the Cavalcade centro area were hoed at 4 weeks after emergence. Carbofuran insecticide (3\% a.i.) at $37.5 \mathrm{~kg} / \mathrm{ha}$ was applied to the sorghum area after sowing. After covering the sorghum seeds, the plots were sprayed with preemergence Atrazine herbicide at a rate of $2.19 \mathrm{~kg} / \mathrm{ha}$ to control weeds. At 7 days after emergence, seedlings were thinned to allow a spacing of 1 plant per $10 \mathrm{~cm}$ and weeding was carried out 1 week later. 
Fertilizer at $600 \mathrm{~kg} \mathrm{~N} / \mathrm{ha}$ was applied to the main crop of sorghum as equal split dressings at 2, 4 and 8 weeks after emergence (WAE) and to the ratoon crop at 2 and 4 weeks after harvesting of the main crop (WAC). Potassium fertilizer at $100 \mathrm{~kg} \mathrm{~K} / \mathrm{ha}$ was applied to the main and ratoon crops as equal split dressings at 2 and 4 WAE and WAC, respectively.

The sorghum plot was divided into 4 sub-plots, and an area of $4 \mathrm{~m}^{2}$ from each sub-plot was randomly chosen for cutting to measure fresh and DM yields. On 30 August 2008 (11 WAE), 20 plants from each sub-plot were randomly chosen and were squeezed to extract juice for determining sucrose concentration in stems or brix value (as gram unit of sucrose in $100 \mathrm{~g}$ of sucrose solution) using a hand-held refractometer (ATAGO N-1 $\alpha$, Japan). After this sampling, the remainder of the sorghum plots, excluding border rows, was cut at $15 \mathrm{~cm}$ above ground level and the crop allowed to ratoon (Khota et al 2009). The same cutting and measuring methods as for the main crop were used with the ratoon crop at 11 WAC on 15 November 2008. All harvested forage was chopped into lengths of 3-5 cm with a machine chopper, and the chopped plant material was thoroughly mixed for silage making.

For Cavalcade centro, the plot was divided into 4 sub-plots to measure fresh and DM yields using four $1 \mathrm{~m}^{2}$ quadrats in each sub-plot. First cutting was made on 25 August 2008 (11 WAE) for the main crop and on 10 November 2008 (11 WAC) for the second cut. Both cutting heights were made at $15 \mathrm{~cm}$ above ground level (Waipanya and Poonpipat 2006). After yield sampling, all fresh Cavalcade plants, excluding border rows, were cut, dried, chopped (3-5 cm length) and kept in polythene bags for mixing with sorghum before ensiling. Samples of $500 \mathrm{~g}$ of each of the 4 replications of chopped sorghum and Cavalcade hay were oven-dried separately at $60{ }^{\circ} \mathrm{C}$ for $48 \mathrm{~h}$, ground to pass through a $1 \mathrm{~mm}$ sieve and kept in air-tight polythene bags for analyses of DM, CP, neutral detergent fiber (NDF), acid detergent fiber (ADF), acid detergent lignin (ADL) and DMD. Samples of cassava chips were also stored for analyses for chemical composition and DMD.

\section{Silage preparation and experiments}

The experiment had a Completely Randomised Design with 4 replications. The main crop was used in Experiment 1 and the ratoon crop ( $2^{\text {nd }}$ cut for Cavalcade) in Experiment 2. Each had 4 treatments of 4 levels of dried cassava chips, viz. 0 (control), 5, 10 and $15 \%$ of fresh weight of chopped sorghum. Chopped Cavalcade hay
(15\% of fresh weight of chopped sorghum) was thoroughly mixed with chopped sorghum (Khota et al. 2009). A total of $260 \mathrm{~kg}$ of the mixture was divided into 4 equal portions of $65 \mathrm{~kg}$ : 1 portion for the control treatment, with the remaining 3 portions for mixing with the cassava chips at 5,10 and $15 \%$ of the fresh weight of sorghum in the mixture. Cassava chips were added at the appropriate levels for the various treatments to the sorghum-Cavalcade mixture and the combinations thoroughly mixed. Before ensiling, 4 replications of $500 \mathrm{~g}$ of each treatment mixture were randomly sampled for chemical composition and DMD determination. Black polythene bags with a dimension of $61 \times 71 \mathrm{~cm}$ were used to make silage. Each treatment mixture was loaded into 4 polythene bags, $15 \mathrm{~kg}$ each, and compressed tightly, before the remaining air was removed by vacuum pump and the bags were closed immediately. The bags were stored and allowed to ferment under ambient temperature for 5 weeks, when they were opened to assess quality in terms of silage physical characteristics using methods described by Zimmer (1980).

\section{Silage sample collection and assessments}

The silage in each bag was divided into 3 equal sections, viz. top, middle and bottom, and approximately $350 \mathrm{~g}$ from each section was selected and thoroughly mixed to make approximately $1 \mathrm{~kg}$, which was divided into 2 equal parts and stored in air-tight polythene bags at $-20{ }^{\circ} \mathrm{C}$. One part was used to determine gross energy (GE), chemical composition and DMD, and the other for $\mathrm{pH}$ and ammonia-nitrogen $\left(\mathrm{NH}_{3}-\mathrm{N}\right)$ determinations. The frozen silage was thawed and extracted with water as described by Bailey (1985). One portion of extracted water was used to measure $\mathrm{pH}$ using a glass electrode $\mathrm{pH}$ meter (Consort C933, Belgium), and the second for analyzing the $\mathrm{NH}_{3}-\mathrm{N}$. Analyses were performed as follows: $\mathrm{CP}$ and $\mathrm{NH}_{3}-\mathrm{N}$ by the Kjeldahl method; GE using a bomb calorimeter (AOAC 1990); NDF, ADF and ADL by the methods of Van Soest et al. (1991); and DMD at $48 \mathrm{~h}$ in rumens of Brahman cattle by the nylon bag technique described by Ørskov et al. (1980). Digestible energy (DE) and metabolizable energy (ME) were predicted by the formulae: $\mathrm{DE}(\mathrm{MJ} / \mathrm{kg})=19.66 \mathrm{DMD}$ (DMD coefficient) - 0.70 (Minson and Milford 1966); and ME $(\mathrm{MJ} / \mathrm{kg})=0.9613 \mathrm{DE}-1.2276($ WTSR 2010).

\section{Statistical analyses}

The data were statistically analyzed using the SAS software program (SAS 1996). The t-test at the alpha level of 0.05 was used to compare the means of DM yields 
and characteristics of main and ratoon $/ 2^{\text {nd }}$ cut crops before ensiling. The data from the silage experiments were analyzed by one-way analysis of variance and the treatment mean differences were determined by Duncan's New Multiple Range Test (DMRT) at $\mathrm{P}=0.05$.

\section{Results}

\section{Climatic conditions}

The work took place in the rainy season (mid-May-midOctober) and partly in the cold season (mid-OctoberNovember) with climatic conditions recorded from May to November 2008. Rainfall ranged from 70 to $462 \mathrm{~mm}$ per month, and number of rainfall days from 4 to 19 days for November and September, respectively; maximum temperature ranged from 29.7 to $33.0^{\circ} \mathrm{C}$, minimum temperature from 20.5 to $25.8{ }^{\circ} \mathrm{C}$, and average temperature from 25.1 to $29.4{ }^{\circ} \mathrm{C}$, for November and June, respectively; evaporation from 102 to $162 \mathrm{~mm}$ for September and June, respectively; relative humidity from 91 to $82 \%$; sunshine duration from 5.1 to $8.0 \mathrm{~h} / \mathrm{d}$; and solar radiation energy from 187 to $213 \mathrm{cal} / \mathrm{cm}^{2} / \mathrm{d}$ for September and November, respectively.

\section{Crop yields and characteristics before ensiling}

The growing period for main and ratoon $/ 2^{\text {nd }}$ cut crops of sorghum and Cavalcade centro was 11 weeks. Both main crops had DM yields significantly $(\mathrm{P}<0.05)$ higher than their ratoon $/ 2^{\text {nd }}$ cut crops (Table 1 ). Crude protein concentrations for Cavalcade were about double those for sorghum. Fiber concentrations (NDF, ADF) for the main sorghum crop were significantly $(\mathrm{P}<0.05)$ higher than for the ratoon. The main sorghum crop gave a DMD value significantly $(\mathrm{P}<0.05)$ lower than the ratoon, while the opposite was the case for Cavalcade, where DMD of the main crop was higher than that of the $2^{\text {nd }}$ cut. Sucrose concentration in terms of brix value was significantly lower in the main sorghum crop than in the ratoon.

\section{Chemical composition and dry matter degradability of ensiled materials}

Chemical composition of cassava chips was: 91.3, 1.49, 10.4, 4.82 and $2.19 \%$ for DM, CP, NDF, ADF and ADL, respectively; $95.7 \%$ for DMD; and $18.16 \mathrm{MJ} / \mathrm{kg}$ for GE. Increase in cassava chip levels significantly $(\mathrm{P}<0.05)$

Table 1. Dry matter (DM) yield, chemical composition, dry matter degradability (DMD) and brix value of main and ratoon/2 ${ }^{\text {nd }}$ cut crops of sorghum and Cavalcade centro before ensiling.

\begin{tabular}{|c|c|c|c|c|c|c|c|c|c|}
\hline & $\begin{array}{c}\text { DM yield } \\
\text { (kg/ha) }\end{array}$ & $\begin{array}{c}\mathrm{DM} \text { at } \\
\text { harvest }(\%)\end{array}$ & $\begin{array}{c}\text { DM of hay } \\
(\%)\end{array}$ & $\mathrm{CP}$ & NDF & $\begin{array}{c}\text { ADF } \\
(\% \mathrm{DM})\end{array}$ & $\overline{\mathrm{ADL}}$ & $\mathrm{DMD}^{1}$ & $\begin{array}{l}\text { Brix } \\
(\%)\end{array}$ \\
\hline \multicolumn{10}{|l|}{ Sorghum } \\
\hline Main crop & $20,825 \mathrm{a}^{1}$ & $23.1 \mathrm{~b}$ & & $6.1 \mathrm{~b}$ & $69.5 \mathrm{a}$ & $40.5 \mathrm{a}$ & 7.06 & $64.2 b$ & $10.8 \mathrm{~b}$ \\
\hline Ratoon crop & $10,025 b$ & $26.0 \mathrm{a}$ & & $7.2 \mathrm{a}$ & $66.3 b$ & $35.5 b$ & 5.86 & $69.4 \mathrm{a}$ & $13.9 \mathrm{a}$ \\
\hline s.e. & 443.9 & 0.11 & & 0.06 & 0.20 & 0.75 & 0.70 & 0.51 & 0.64 \\
\hline \multicolumn{10}{|l|}{ Cavalcade } \\
\hline Main crop & $2,713 x$ & $18.9 y$ & 91.5 & $14.6 x$ & 53.8 & 37.2 & 7.05 & $71.8 x$ & \\
\hline $2^{\text {nd }}$ cut & $1,781 \mathrm{y}$ & $38.4 x$ & 92.0 & $13.0 \mathrm{y}$ & 54.0 & 37.2 & 8.85 & $67.7 y$ & \\
\hline s.e. & 53.54 & 0.02 & 1.13 & 0.16 & 0.36 & 0.59 & 0.46 & 0.78 & \\
\hline
\end{tabular}

${ }^{1}$ Means within species in the same column followed by different letters differ $(\mathrm{P}<0.05)$.

Table 2. Effects of level of cassava chips on chemical composition and dry matter degradability (DMD), at ensiling, of mixtures of sorghum, Cavalcade centro and cassava chips for main and ratoon $/ 2^{\text {nd }}$ cut crops.

\begin{tabular}{|c|c|c|c|c|c|c|c|c|c|c|}
\hline \multirow[t]{2}{*}{ Parameter } & \multicolumn{4}{|c|}{ Level of cassava chips (\%) } & \multirow[b]{2}{*}{ s.e. } & \multicolumn{4}{|c|}{ Level of cassava chips (\%) } & \multirow[b]{2}{*}{ s.e. } \\
\hline & 0 & 5 & 10 & 15 & & 0 & 5 & 10 & 15 & \\
\hline & \multicolumn{4}{|c|}{ Main crop } & & \multicolumn{4}{|c|}{ Ratoon $/ 2^{\text {nd }}$ cut crop } & \\
\hline $\mathrm{DM}(\%)$ & $33.6 c^{1}$ & $34.8 \mathrm{bc}$ & $36.4 \mathrm{~b}$ & $39.0 \mathrm{a}$ & 0.70 & $33.0 \mathrm{c}$ & $37.0 \mathrm{~b}$ & $38.0 \mathrm{ab}$ & $39.8 \mathrm{a}$ & 0.68 \\
\hline $\mathrm{CP}(\%)$ & $9.26 \mathrm{a}$ & $8.59 \mathrm{ab}$ & $7.97 \mathrm{bc}$ & $7.80 \mathrm{c}$ & 0.21 & $9.16 \mathrm{a}$ & $8.53 b$ & $7.61 \mathrm{c}$ & $7.24 \mathrm{~d}$ & 0.07 \\
\hline $\operatorname{NDF}(\%)$ & $67.5 \mathrm{a}$ & $63.3 \mathrm{~b}$ & $57.4 \mathrm{c}$ & $55.1 \mathrm{~d}$ & 0.54 & $66.1 \mathrm{a}$ & $62.4 \mathrm{~b}$ & $60.4 \mathrm{c}$ & $54.7 \mathrm{~d}$ & 0.56 \\
\hline $\operatorname{ADF}(\%)$ & $43.2 \mathrm{a}$ & $41.0 \mathrm{ab}$ & $39.0 \mathrm{bc}$ & $37.1 \mathrm{c}$ & 0.88 & $39.8 \mathrm{a}$ & $37.5 \mathrm{a}$ & $32.0 \mathrm{~b}$ & $31.1 \mathrm{~b}$ & 0.77 \\
\hline $\operatorname{ADL}(\%)$ & 7.40 & 6.45 & 6.42 & 5.65 & 0.70 & 6.19 & 5.41 & 5.26 & 5.18 & 0.50 \\
\hline $\operatorname{DMD}(\%)$ & $65.1 \mathrm{~d}$ & $66.6 \mathrm{c}$ & $69.0 \mathrm{~b}$ & $70.4 \mathrm{a}$ & 0.38 & $66.5 \mathrm{c}$ & $67.9 \mathrm{cb}$ & $69.8 \mathrm{~b}$ & $72.9 \mathrm{a}$ & 0.64 \\
\hline
\end{tabular}

${ }^{\mathrm{T}}$ Means within crops in the same row followed by different letters differ $(\mathrm{P}<0.05)$. 
increased DM and lowered $\mathrm{CP}, \mathrm{NDF}$ and $\mathrm{ADF}$ concentrations in mixtures for both main and ratoon $/ 2^{\text {nd }}$ cut crops at ensiling (Table 2). Dry matter degradability significantly $(\mathrm{P}<0.05)$ increased with an increase in cassava chip levels.

\section{Gross energy, digestible energy and metabolizable energy of ensiled materials}

Level of cassava chips had no effect on GE levels in ensiled material $(\mathrm{P}>0.05)$ (Table 3 ), while both $\mathrm{DE}$ and ME increased significantly $(\mathrm{P}<0.05)$ with increasing cassava chip levels. The highest values of DE and ME were found with the highest level of cassava chips (15\%) for both crops.

\section{Characteristics of silages}

Dry matter contents of silages from both crops increased significantly with an increase in cassava chip levels
(Table 4). Adding cassava chips significantly increased $\mathrm{pH}$ values of the ratoon $/ 2^{\text {nd }}$ cut crop silage but not of the main crop silage. Cassava chip level had no significant effect on $\mathrm{NH}_{3}-\mathrm{N}$ concentrations in the silages.

\section{Chemical composition and dry matter degradability of silages}

Neutral detergent fiber, ADF and CP concentrations decreased significantly with increase in cassava chips in both crop silages (Table 5), while DMD increased significantly as level of cassava chips increased for both crops.

\section{Gross energy, digestible energy and metabolizable energy of silages}

Cassava chip levels had no significant effect on GE (Table 6), but both DE and ME increased with increasing levels of cassava chips.

Table 3. Effects of level of cassava chips on gross energy (GE), digestible energy (DE) and metabolizable energy (ME), at ensiling, of mixtures of sorghum, Cavalcade centro and cassava chips for main and ratoon $/ 2^{\text {nd }}$ cut crops.

\begin{tabular}{|c|c|c|c|c|c|c|c|c|c|c|}
\hline \multirow{2}{*}{ Parameter } & \multicolumn{4}{|c|}{ Level of cassava chips (\%) } & \multirow[b]{2}{*}{ s.e. } & \multicolumn{4}{|c|}{ Level of cassava chips (\%) } & \multirow[b]{2}{*}{ s.e. } \\
\hline & 0 & 5 & 10 & 15 & & 0 & 5 & 10 & 15 & \\
\hline & \multicolumn{4}{|c|}{ Main crop } & & \multicolumn{4}{|c|}{ Ratoon $/ 2^{\text {nd }}$ cut crop } & \\
\hline $\mathrm{GE}(\mathrm{MJ} / \mathrm{kg})$ & 20.55 & 16.79 & 17.39 & 17.12 & 1.37 & 13.91 & 16.14 & 16.48 & 17.34 & 0.98 \\
\hline $\mathrm{DE}(\mathrm{MJ} / \mathrm{kg})$ & $12.10 \mathrm{~d}^{1}$ & $12.39 \mathrm{c}$ & $12.87 \mathrm{~b}$ & $13.15 \mathrm{a}$ & 0.075 & $12.38 \mathrm{c}$ & $12.64 \mathrm{bc}$ & $13.03 \mathrm{~b}$ & $13.64 \mathrm{a}$ & 0.126 \\
\hline $\mathrm{ME}(\mathrm{MJ} / \mathrm{kg})$ & $10.41 \mathrm{~d}$ & $10.68 \mathrm{c}$ & $11.15 \mathrm{~b}$ & $11.41 \mathrm{a}$ & 0.072 & $10.68 \mathrm{c}$ & $10.93 b c$ & $11.28 \mathrm{~b}$ & $11.87 \mathrm{a}$ & 0.119 \\
\hline
\end{tabular}

${ }^{\mathrm{T}}$ Means within crops in the same row followed by different letters differ $(\mathrm{P}<0.05)$.

Table 4. Effects of level of cassava chips on characteristics of silages made from mixtures of sorghum forage, Cavalcade centro and cassava chips for main and ratoon $/ 2^{\text {nd }}$ cut crops.

\begin{tabular}{|c|c|c|c|c|c|c|c|c|c|c|}
\hline \multirow{2}{*}{ Parameter } & \multicolumn{4}{|c|}{ Level of cassava chips (\%) } & \multirow[b]{2}{*}{ s.e. } & \multicolumn{4}{|c|}{ Level of cassava chips (\%) } & \multirow[b]{2}{*}{ s.e. } \\
\hline & 0 & 5 & 10 & 15 & & 0 & 5 & 10 & 15 & \\
\hline & \multicolumn{4}{|c|}{ Main crop } & & \multicolumn{4}{|c|}{ Ratoon $/ 2^{\text {nd }}$ cut crop } & \\
\hline $\mathrm{DM}(\%)$ & $33.3 \mathrm{~d}^{1}$ & $34.8 \mathrm{c}$ & $38.2 \mathrm{~b}$ & $39.9 \mathrm{a}$ & 0.40 & $33.0 \mathrm{c}$ & $35.2 \mathrm{~b}$ & $37.4 \mathrm{a}$ & $38.9 \mathrm{a}$ & 0.48 \\
\hline $\mathrm{pH}$ & 3.83 & 3.78 & 3.81 & 3.80 & 0.02 & $4.04 \mathrm{~b}$ & $4.08 \mathrm{ab}$ & $4.11 \mathrm{a}$ & $4.13 \mathrm{a}$ & 0.02 \\
\hline $\mathrm{NH}_{3}-\mathrm{N}(\%$ total $\mathrm{N})$ & 1.64 & 1.87 & 1.89 & 1.89 & 0.23 & 1.65 & 1.88 & 1.88 & 1.88 & 0.24 \\
\hline
\end{tabular}

${ }^{\mathrm{T}}$ Means within crops in the same row followed by different letters differ $(\mathrm{P}<0.05)$.

Table 5. Effects of level of cassava chips on chemical composition and dry matter degradability (DMD) of silages made from mixtures of sorghum forage, Cavalcade centro and cassava chips for main and ratoon $/ 2^{\text {nd }}$ cut crops.

\begin{tabular}{|c|c|c|c|c|c|c|c|c|c|c|}
\hline \multirow[t]{2}{*}{ Parameter } & \multicolumn{4}{|c|}{ Level of cassava chips (\%) } & \multirow[b]{2}{*}{ s.e. } & \multicolumn{4}{|c|}{ Level of cassava chips (\%) } & \multirow[b]{2}{*}{ s.e. } \\
\hline & 0 & 5 & 10 & 15 & & 0 & 5 & 10 & 15 & \\
\hline & \multicolumn{4}{|c|}{ Main crop } & & \multicolumn{4}{|c|}{ Ratoon $/ 2^{\text {nd }}$ cut crop } & \\
\hline $\mathrm{CP}(\%)$ & $8.74 \mathrm{a}^{1}$ & $8.43 b$ & $7.67 \mathrm{c}$ & $6.86 \mathrm{~d}$ & 0.06 & $8.65 \mathrm{a}$ & $7.84 \mathrm{~b}$ & $7.56 \mathrm{~b}$ & $7.15 \mathrm{c}$ & 0.11 \\
\hline $\operatorname{NDF}(\%)$ & $65.8 \mathrm{a}$ & $63.6 \mathrm{~b}$ & $59.6 \mathrm{c}$ & $57.9 \mathrm{~d}$ & 0.42 & $65.3 \mathrm{a}$ & $64.4 \mathrm{a}$ & $58.9 \mathrm{~b}$ & $55.6 \mathrm{c}$ & 0.38 \\
\hline $\mathrm{ADF}(\%)$ & $41.2 \mathrm{a}$ & $39.8 \mathrm{a}$ & $36.6 \mathrm{~b}$ & $35.7 \mathrm{~b}$ & 0.57 & $35.4 \mathrm{a}$ & $32.1 \mathrm{~b}$ & $30.8 \mathrm{bc}$ & $29.3 \mathrm{c}$ & 0.72 \\
\hline $\operatorname{ADL}(\%)$ & 6.03 & 5.35 & 5.26 & 5.24 & 0.34 & 4.81 & 4.61 & 4.68 & 4.61 & 0.29 \\
\hline $\operatorname{DMD}^{2}(\%)$ & $65.0 \mathrm{~b}$ & $66.0 \mathrm{~b}$ & $69.2 \mathrm{a}$ & $69.4 \mathrm{a}$ & 0.39 & $70.4 \mathrm{~b}$ & $71.7 \mathrm{~b}$ & $73.7 \mathrm{a}$ & $75.3 \mathrm{a}$ & 0.60 \\
\hline
\end{tabular}

${ }^{\mathrm{T}}$ Means within crops in the same row followed by different letters differ $(\mathrm{P}<0.05)$. 
Table 6. Effects of level of cassava chips on gross energy (GE), digestible energy (DE) and metabolizable energy (ME) of silages made from mixtures of sorghum forage, Cavalcade centro and cassava chips for main and ratoon $/ 2^{\text {nd }}$ cut crops.

\begin{tabular}{|c|c|c|c|c|c|c|c|c|c|c|}
\hline \multirow[t]{2}{*}{ Parameter } & \multicolumn{4}{|c|}{ Level of cassava chips (\%) } & \multirow[b]{2}{*}{ s.e. } & \multicolumn{4}{|c|}{ Level of cassava chips (\%) } & \multirow[b]{2}{*}{ s.e. } \\
\hline & 0 & 5 & 10 & 15 & & 0 & 5 & 10 & 15 & \\
\hline & \multicolumn{4}{|c|}{ Main crop } & \multicolumn{6}{|c|}{ Ratoon $/ 2^{\text {nd }}$ cut crop } \\
\hline /kg) & 18.55 & 20.80 & 19.57 & 19.15 & 0.91 & 18.91 & 18.65 & 17.87 & 17.63 & 0.41 \\
\hline $\mathrm{DE}^{2}(\mathrm{MJ} / \mathrm{kg})$ & $12.08 \mathrm{~b}^{1}$ & $12.27 \mathrm{~b}$ & $12.91 \mathrm{a}$ & $12.94 \mathrm{a}$ & 0.070 & $13.15 c$ & $13.40 \mathrm{c}$ & $13.80 \mathrm{~b}$ & $14.11 \mathrm{a}$ & 0.096 \\
\hline $\mathrm{ME}^{3}(\mathrm{MJ} / \mathrm{kg})$ & $10.38 \mathrm{~b}$ & $10.57 \mathrm{~b}$ & $11.18 \mathrm{a}$ & $11.21 \mathrm{a}$ & 0.076 & $11.41 \mathrm{c}$ & $11.66 \mathrm{c}$ & $12.03 \mathrm{~b}$ & $12.34 \mathrm{a}$ & 0.092 \\
\hline
\end{tabular}

${ }^{\mathrm{T}}$ Means within crops in the same row followed by different letters differ $(\mathrm{P}<0.05)$.

\section{Discussion}

This study has shown that good quality silage can be made from mixtures of forage sorghum, Cavalcade centro hay and cassava chips, regardless of whether first cut or second cut forage is used. When cut at 11 weeks after sowing or at 11 weeks of regrowth, the silages had CP concentrations of 8.7 to $6.9 \%$, DMD of $65-75 \%$ and $\mathrm{pH}$ of 3.8-4.1, depending on how much cassava chip was added. This indicated that there was enough WSC in terms of brix values in main $(10.84 \%)$ and ratoon $(13.85 \%)$ crops of sorghum with addition of Cavalcade hay $(15 \%)$ and cassava chip levels $(0-15 \%)$ to make good quality silage.

Available soil moisture levels could have contributed to the differences in yield of the main and ratoon crops of sorghum and Cavalcade centro, as the main crops were grown in the rainy season (mid-May-mid-October) and the ratoon crops partly in both rainy and cold seasons (September-mid-February). Hence soil moisture levels would have been adequate for the main crop and the early regrowth of the ratoon crop, while declining rainfall in October and only $69.9 \mathrm{~mm}$ over 4 days of rainfall in November could have limited growth. Differences in hours of sunlight and daily temperature could have played a part as well.

Sorghum and Cavalcade both produce floral parts late in the season, since they are short-day plants (Cook et al. 2005). In Thailand, Cavalcade starts to flower in midOctober and mature seed can be harvested in midJanuary (Phunphiphat et al. 2004). Dry matter yield and $\mathrm{CP}$ concentration of Cavalcade centro in the present work were lower than the $7,456 \mathrm{~kg} / \mathrm{ha} / \mathrm{yr}$ at $16.5 \% \mathrm{CP}$ reported by Phunphiphat et al. (2008), although our data are for 22 weeks production only. Main crop sorghum commenced flowering in late August. High vegetative growth rates of sorghum early in the season resulted in higher DM yield and fiber concentration in forage from the main crop than from the ratoon. The short period of vegetative growth of ratoon sorghum late in the season accelerated flowering and resulted in fully developed seeds with higher starch content than in the main crop. The resulting higher ADF and ADL concentrations in forage from the main crop and virtual absence of seed were reflected in higher DMD and brix values for the ratoon. With Cavalcade, the very high rainfall with high relative humidity of $91 \%$ in September caused canopy die-back in the lower layers from fungal attack. This led to a decrease in $\mathrm{CP}$ concentration and DM yield of Cavalcade at the second harvest. The higher ADL concentration of the $2^{\text {nd }}$ cut Cavalcade also resulted in lower DMD than in the main crop. ADL has an important role in limiting cell wall (NDF) degradability, i.e. the higher the ADL content the poorer the digestibility (Van Soest 1978; Minson 1990).

In main crops, DMD of Cavalcade was higher than that of sorghum, but in ratoon $/ 2^{\text {nd }}$ cut crops, sorghum was more digestible than Cavalcade. This could be attributed to high carbohydrate levels in seed of ratoon sorghum aiding digestibility, as reflected in the higher brix values of forage from the ratoon (13.9 vs. 10.8\%). Forage legumes normally have higher digestibility than tropical grasses; Devahuti et al. (1992) reported that tropical grasses (14 species, 59 samples) had mean DMD values of $66.7 \%$, which was lower than for tropical forage legumes (7 species, 14 samples, $72.5 \%$ DMD). A range of $41-60 \%$ DMD in grasses and 69-79\% DMD in forage legumes was reported by Ibrahim et al. (1995). Therefore, when legume forage is ensiled with forage sorghum, the result is a significantly higher DMD than for sorghum alone (Khota et al. 2009).

The higher sucrose concentration (brix value) of ratoon sorghum than in the main crop reflected the greater seed head development and greater plant maturity in the ratoon crop at harvest. This is in agreement with a number of other reports; brix value and WSC in tropical grasses increase with an increase in cutting ages (Kunapongkiti et al. 2004). Pholsen and Suksri (2007) reported brix values with the same cultivar of main crop sorghum ranging from 10.6 to $11.8 \%$. Higher brix values in ratoon than main crop sorghum were also reported by Rao et al. (2011). 
Cavalcade centro was considered most suitable for silage making because it accumulated more WSC than other tropical forage legumes, viz. 6.08 \pm 0.09 and $6.22 \pm 3.35 \%$ at 60 and 90 days after emergence, respectively, compared with $3.43 \pm 1.34$ and $4.90 \pm 0.18 \%$ for Verano stylo (Stylosanthes hamata cv. Verano) (Kunapongkiti et al. 2004). Brix value reflects sucrose concentration, which, along with other WSCs in forages, is an important source of energy for bacteria to produce lactic acid in the silage fermentation process. Namsele et al. (2007) reported $\mathrm{pH} 4.53$ for Cavalcade silage attained from its WSC of $5.1 \%$ and $\mathrm{pH} 4.90$ for Stylosanthes guianensis CIAT 184 with WSC of $2.9 \%$.

For both ensiled materials and silages of both main and ratoon crops, DM contents significantly increased as cassava chip level increased with values ranging from 33.0 to $39.8 \%$. This is attributable to the high DM content $(91.2 \%)$ of added cassava chip. Church and Pond (1988) and Wilkinson (1990) suggest that high quality silage requires $25-35 \%$ DM and preferably 30-35\%. Dry matter contents in this range of silage in our study were achieved with inclusion of no cassava or $5 \%$ of cassava chips.

Cassava chip levels did not significantly affect $\mathrm{pH}$ and $\mathrm{NH}_{3}-\mathrm{N}$ of silages except for $\mathrm{pH}$ of ratoon $/ 2^{\text {nd }}$ cut crop silage. Ranges of $\mathrm{pH}$ for both silages were from 3.78 to 4.13 and $\mathrm{NH}_{3}-\mathrm{N}$ from 1.64 to $1.89 \%$ of total $\mathrm{N}$. Oude Elferink et al. (2000) and Khota et al. (2009) have shown that the rapid lowering of $\mathrm{pH}$ to $<4.0$ inhibits the growth of enterobacteria and clostridia, which break down protein in the silage to form ammonia. The low $\mathrm{NH}_{3}-\mathrm{N}$ in this study shows cassava chips are a good source of WSC that will lower $\mathrm{pH}$ and reduce $\mathrm{NH}_{3}-\mathrm{N}$ production. On the basis of $\mathrm{pH}, \mathrm{NH}_{3}-\mathrm{N}$ values and physical characteristics, both silages were defined as of good quality (Zimmer 1980; Skerman and Riveros 1990).

While addition of cassava chips increased the degradability and ME of the sorghum-Cavalcade centro silage, it did reduce the $\mathrm{CP}$ concentration. However, the $\mathrm{CP}$ concentrations in all silages were above the $7 \%$ critical level, at which nitrogen becomes limiting for rumen microorganism activity and feed intake is depressed (Milford and Minson 1966). However, in order to attain higher protein levels in the final product, fresh Cavalcade could be substituted for Cavalcade hay, as CP concentrations in fresh material would be higher than in hay.

The decrease in NDF and ADF with increase in cassava chip levels could be attributable to levels of carbohydrates in cassava chips diluting fiber content. Neutral detergent fiber of both silages in this work at cassava chip levels of 10 and $15 \%$ addition was lower than reported by Black et al. (1980) and Miron et al. (2007).
Higher fiber concentrations in forage lower digestibility (Van Soest 1978; Chaves et al. 2002). The significant decrease in NDF due to higher cassava chip levels led to significantly increased DMD in both main and ratoon crops of the mixed ensiled materials. The added cassava chip levels could have aided digestibility of both silages due to the high DMD of cassava chips (95.7\%), as high DM digestibility of cassava chips in the rumen was reported by Chanjula et al. (2003).

\section{Conclusions}

Adding of cassava chips to mixtures of freshly chopped forage sorghum and chopped Cavalcade centro hay (Cavalcade at $15 \%$ of sorghum fresh weight) at ensiling will improve the quality of the resulting silage in terms of DM, DMD, DE and ME. However, CP concentration in the resulting silage is significantly lowered, when $15 \%$ cassava chip is added. The use of fresh legume should be explored to improve CP levels in the silage, along with feeding studies with animals to measure animal performance.

\section{Acknowledgment}

The authors thank the Tropical Feed Resources Research and Development Center (TROFREC) of Khon Kaen University for financial assistance.

\section{References}

AOAC. 1990. Official methods of analysis of the Association of Official Analytical Chemists. 15th Edn. Benjamin Franklin Station, Washington, DC, USA.

Bailey S. 1985. The Analysis of Agricultural Materials. 3rd Edn. Reference book 427, Her Majesty's Stationery Office, London, UK.

Black JR; Ely LO; McCullough ME; Sudweeks EM. 1980. Effects of stage of maturity and silage additives upon the yield of gross and digestible energy in sorghum silage. Journal of Animal Science 50:617-624. http://goo.gl/ AEmTa1

Chanjula P; Wanapat M; Wachirapakorn C; Uriyapongson S; Rowlinson P. 2003. Ruminal degradability of tropical feeds and their potential use in ruminant diets. AsianAustralasian Journal of Animal Sciences 16:211-216.

Chaves AV; Waghorn GC; Brookes IM; Hedderley D. 2002. Digestion kinetics of ryegrass. Proceedings of the New Zealand Society of Animal Production 62:157-162. http://goo.gl/VjGyLP

Church DC; Pond WG. 1988. Basic Animal Nutrition and Feeding. 3rd Edn. John Wiley \& Sons, New York, USA.

Cook BG; Pengelly BC; Brown SD; Donnelly JL; Eagles DA; Franco MA; Hanson J; Mullen BF; Partridge IJ; Peters M; 
Schultze-Kraft R. 2005. Tropical forages: an interactive selection tool. [CD-ROM], CSIRO, DPI\&F (Qld), CIAT and ILRI, Brisbane, Australia. http://goo.gl/DK8GHy

Devahuti P; Phaikaew C; Tawatun H; Boonpukdee W. 1992. Relationship between in vivo nylon bag and pepsin cellulase in vitro dry matter digestibility of some tropical forage species. An Annual Research Report 1992, Department of Livestock Development, Ministry of Agriculture and Cooperatives, Bangkok, Thailand.

Ibrahim MNM; Tamminga S; Zemmelink G. 1995. Degradation of tropical roughages and concentrate feeds in the rumen. Animal Feed Science and Technology 54:81-92.

Khota W; Pholsen S; Rodchum P. 2009. Effect of Cavalcade (Centrosema pascuorum cv. Cavalcade) hay additive on silage quality of forage sorghum (Sorghum bicolor L. Moench). In: Proceedings of Greater Mekong Sub-region Conference on Sustainable Development, Nakhon Phanom 2009. Nakhon Phanom University, Nakhon Phanom, Thailand. p. 109-116. http://goo.gl/SF5ca7

Khuamangkorn P; Klum-em K; Martosot S. 2006. Effect of using additives on silage quality of Pangola grass. An Annual Research Report 2006, Department of Livestock Development, Ministry of Agriculture and Cooperatives, Bangkok, Thailand.

Kunapongkiti S; Boonjaratcha J; Ketkamalas S. 2004. The study on relationship between WSC and sweetness of forage juice at various cutting intervals. An Annual Research Report 2004, Department of Livestock Development, Ministry of Agriculture and Cooperatives, Bangkok, Thailand.

McDonald P; Henderson AR; Heron SJE. 1991. The biochemistry of silage. 2nd Edn. Chalcombe Publications, Marlow, Buckinghamshire, UK.

Milford R; Minson DJ. 1966. Intake of tropical pasture species. In: Proceedings of the IX International Grassland Congress, São Paulo, Brazil, 1965. p. 814-822.

Minson DJ. 1990. Forage in ruminant nutrition. Academic Press, New York, USA.

Minson DJ; Milford R. 1966. The energy values and nutritive value indices of Digitaria decumbens, Sorghum almum and Phaseolus atropurpureus. Australian Journal of Agricultural Research 17: 411-423. DOI: 10.1071/AR9660411

Miron J; Zuckerman E; Adin G; Solomon R; Shoshani E; Nikbachat M; Yosef E; Zenou A; Weinberg ZG; Chen Y; Halachmi I; Ben-Ghedalia D. 2007. Comparison of two forage sorghum varieties with corn and effect of feeding their silages on eating behaviour and lactation performance of dairy cows. Animal Feed Science and Technology 139:23-39. http://goo.gl/vFGO94

Namsele R; Khuamangkorn P; Pholsen P; Martosot S. 2007. The study on silage quality of Ruzi (Brachiaria ruziziensis), Thapra Stylo (Stylosanthes guianensis CIAT 184), Pangola (Digitaria eriantha) and Cavalcade (Centrosema pascuorum cv. Cavalcade) at different stages of fermentation. An Annual Research Report 2007, Department of Livestock Development, Ministry of Agriculture and Cooperatives, Bangkok, Thailand.
Ørskov ER; Hovell FDD; Mould F. 1980. The use of the nylon bag technique for the evaluation of feedstuffs. Tropical Animal Production 5:195-213.

Oude Elferink SJWH; Driehuis F; Gottschal JC; Spoelstra SF. 2000. Silage fermentation processes and their manipulation. In: Mannetje L't, ed. Silage Making in the Tropics with Particular Emphasis on Smallholders. Proceedings of the FAO Electronic Conference on Tropical Silage. http://goo.gl/ecj0CS

Phaikaew C; Boonpukdee W; Srakoopan S; Arkahat K. 1992. Yield and nutritive value of forage sorghum line UT 203 at different cutting intervals. An Annual Research Report 1992, Department of Livestock Development, Ministry of Agriculture and Cooperatives, Bangkok, Thailand.

Phaikaew C; Pholsen P; Chompooso B. 2003. A testing sweet sorghum for silage making. An Annual Research Report 2003, Department of Livestock Development, Ministry of Agriculture and Cooperatives, Bangkok, Thailand.

Pholsen S; Kasikranan S; Pholsen P; Suksri A. 1998. Dry matter yield, chemical compositions and dry matter degradability of ten sorghum cultivars (Sorghum bicolor L. Moench) grown on Oxic Paleustults soil. Pakistan Journal of Biology Sciences 1:228-231. http://goo.g1/RXwdzh

Pholsen S; Higgs DEB; Suksri A. 2001. Effect of nitrogen and potassium fertilizers on growth, chemical component and seed yield of forage sorghum (Sorghum bicolor L. Moench) grown on Oxic Paleustults Soil Northeast Thailand. Pakistan Journal of Biology Sciences 4:27-31. http://goo.gl/dCoCqT

Pholsen S; Sornsungnoen N. 2004. Effects of nitrogen and potassium rates and planting distances on growth, yield and fodder quality of a forage sorghum (Sorghum bicolor L. Moench). Pakistan Journal of Biology Sciences 7:1793-1800. http://goo.gl/YrPXvY

Pholsen S; Higgs DEB. 2005. Effect of main crop cutting age on growth, dry weight yield and fodder quality of main crop and ratoon crop of IS 23585 forage sorghum cultivar. In: Rowlinson P; Wachirapakorn C; Pakdee P; Wanapat $\mathrm{M}$, eds. Proceedings of Conference on Integrating livestock-crop systems to meet the challenges of globalisation. AHAT/BSAS International Conference, Khon Kaen, Thailand. Document T137. http://goo.gl/39thC4

Pholsen S; Suksri A. 2007. Effects of phosphorus and potassium on growth, yield and fodder quality of IS 23585 forage sorghum cultivar (Sorghum bicolor L. Moench). Pakistan Journal of Biology Sciences 10:1604-1610. http://goo.gl/dlT8ji

Phunphiphat R; Phunphiphat W; Kulna S. 2004. Effect of cutting interval on seed yield and quality of Cavalcade Centurion (Centrosema pascuorum cv. Cavalcade) in $\mathrm{Su}-$ khothai Province. An Annual Research Report 2004, Department of Livestock Development, Ministry of Agriculture and Cooperatives, Bangkok, Thailand.

Phunphiphat R; Klum-em K; Phunphiphat W. 2008. Effect of plant spacing and cutting interval on yield and chemical composition of Centrosema pascuorum cv. Cavalcade. An Annual Research Report 2008, Department of Livestock 
Development, Ministry of Agriculture and Cooperatives, Bangkok, Thailand.

Pongpeajan S; Arananant J; Waipanya S. 2008. Effect of silage additives on silage quality of Napier grass. An Annual Research Report 2008, Department of Livestock Development, Ministry of Agriculture and Cooperatives, Bangkok, Thailand.

Pothisoong T; Piyapanthawanon S; Nilpayak T. 2005. KDF 404 Forage sorghum variety. In: Proceedings of the $43^{\text {rd }}$ Kasetsart University Annual Conference, Bangkok, Thailand. p. 591-595. http://goo.gl/CZl7wZ

Rao PS; Jayalakshmi M; Kuma CG; Kamal A; Reddy BVS. 2011. Response of fertilizer treatments on agronomic and biochemical traits in main and ratoon crops of sweet sorghum (Sorghum bicolor (L.) Moench) cultivar ICSV 93046. In: The IAPSIT International Sugar Conference, New Delhi, India. p. 1-11. http://goo.gl/dASeIj

Sangchote S; Punyavirocha T; Kanjanpibul N. 1992. Nutritive value of sugarcane top and leucaena leaves silage. An Annual Research Report 1992, Department of Livestock Development, Ministry of Agriculture and Cooperatives, Bangkok, Thailand.

SAS. 1996. SAS/STAT User's Guide. Version 6.12. SAS Institute Inc., Cary, NC, USA.

Senanarong A. 1977. Introductory address for the ninth national corn and sorghum reporting session. In: Senanarong A, ed. Thailand National Corn and Sorghum Program. 1977 Annual Report, Kasetsart University and Department of Agriculture, Bangkok, Thailand.

Skerman PJ; Riveros F. 1990. Tropical grasses. FAO Plant Production and Protection Series. Food and Agriculture Organization of the United Nations (FAO), Rome, Italy.
Suchato W; Boontum A; Sitthithai P; Suriyapan P. 1991. Study on planting time of sorghum for forage and grain yield for ratoon. Thai Agricultural Research Journal 9:17-20. http://goo.gl/p6nC6E

Van Soest PJ. 1978. Preharvest factors influencing quality of conserved forage. Journal of Animal Science 47:712-720. http://goo.gl/SiwnMC

Van Soest PJ; Robertson JB; Lewis BA. 1991. Method of dietary fiber, neutral detergent fiber and non starch polysaccharides in relation to animal nutrition. Journal of Dairy Science 74:3583-3597. http://goo.gl/b9STjq

Waipanya S; Poonpipat R. 2006. Effects of sowing dates on yields of Cavalcade legume plants. An Annual Research Report 2006, Department of Livestock Development, Ministry of Agriculture and Cooperatives, Bangkok, Thailand.

Wilkinson JM. 1990. Silage UK. 6th Edn. Chalcombe Publications, Marlow, Buckinghamshire, UK.

WTSR (Working Committee of Thai Feeding Standard for Ruminant). 2010. Nutrient requirements of beef cattle in Indochinese peninsula. 1st Edn. Klung Nana Vithya Press Limited Partnership, Khon Kaen, Thailand.

Zimmer E. 1980. Efficient silage systems. In: Thomas C, ed. Proceedings of a Conference on Forage Conservation in the 80's. British Grassland Society Occasional Symposium No. 11, Brighton, 27-30 November 1979. Janssen Services, London, UK.

(Received for publication 23 October 2013; accepted 29 June 2014)

Tropical Grasslands-Forrajes Tropicales is an open-access journal published by Centro Internacional de Agricultura Tropical (CIAT). This work is licensed under a Creative Commons Attribution-NonCommercial-ShareAlike 3.0 Unported License. To view a copy of this license, visit http://creativecommons.org/licenses/by-nc-sa/3.0/ 
Pholsen S; Yoottasanong C; Higgs DEB; Adjorlolo LK. 2014. Effect of cassava chips on quality of silage from fresh forage sorghum plus Cavalcade forage legume hay mixtures. Tropical Grasslands - Forrajes Tropicales 2:262-270.

DOI: $\underline{\text { 10.17138/TGFT(2)262-270 }}$ 